\title{
EXPERIMENTAL STUDY OF PRODUCTION AND CHARACTERIZATION OF DATE FRUIT POWDERS AND SYRUP
}

\author{
Amal Messaoudi ${ }^{1 \bowtie}$, Djamel Fahloul $^{1}$ \\ ${ }^{I}$ Department of Food Technology, Food Sciences Laboratory (LSA), \\ Hadj Lakhdar Batna 1 University, Batna, Algeria. \\ ${ }^{凶}$ Messaoudi_Amel@live.fr \\ https://doi.org/10.34302/crpjfst/2020.12.3.17 \\ Article history: \\ Received: \\ 20 December 2018 \\ Accepted: \\ 15 April 2020 \\ Keywords: \\ Date; \\ Functional; \\ Mathematical modeling; \\ Physicochemical; \\ Powders.

\section{ABSTRACT} \\ In the present work, date pulp and pomace powders were produced under \\ freeze drying conditions and syrup was extracted from Garn Ghzel date \\ variety. Date products were characterized in terms of physicochemical \\ properties (moisture, water activity, ash, soluble solids content, titrable \\ acidity, $\mathrm{pH}$ and color) and functional properties (water holding capacity, \\ wettability index, dispersibility and density). Freeze drying kinetic of date \\ pulp and pomace was modeled using five empirical models (Newton, Page, \\ Henderson and Papis, Logarithmic and Wang and Singh). Results showed \\ that there is a slight difference between powders properties. Page and \\ Logarithmic models best fitted the freeze drying kinetic of date pulp and \\ pomace with the highest determination coefficient, $\mathrm{R}^{2}(0.9635)$ and $\quad \mathrm{R}^{2}$ \\ (0.9987) and the lowest chi-square $\chi^{2}(0.000021)$ and $\chi^{2}(0.000052)$ values \\ respectively. Fick's law was used to determine the effective moisture \\ diffusivity. Its values were $9.74 \times 10^{-11}$ and $5.15 \times 10^{-11} \mathrm{~m}^{2} / \mathrm{s}$ for date pulp \\ and pomace respectively. These results contribute added value to date \\ technology.
}

\section{Introduction}

Date palm (Phoenix dactylifera L.) is extensively cultivated for its edible fruit belonging to the Palmae (Arecaceae) family (Yahaya et al., 2015). The fruit of date palm is used due to its remarkable nutritional, health and economic value, in addition to its aesthetic and environmental benefits. Date composition is rich in carbohydrates, minerals, dietary fiber, vitamins, fatty acids, amino acids and protein $\operatorname{diet}$ (Al-Shahib and Marshall, 2003).

Algeria is one of the largest date producers in the world with a wide production diversity. Garn Ghzel variety is not widely consumed despite its high total and reducing sugar contents (Mrabet et al., 2008). Date processing industries produce various date products such as paste, syrup, jam and vinegar. Date syrup is probably the most common derived date product (Ganbi,
2012). Production of date powder could improve handling, storage and blending ability of several products such as baked foods (Manickavasagan et al., 2015).

In recent years, drying operations have made possible the production of various added value food products (Omolola et al., 2015). Freeze drying is a drying method used to manufacture pharmaceutical and food thermolabile products (Nireesha et al., 2013). It is considered a low processing drying method.

To our knowledge, no work has been reported on the production of powders from date pomace as well as the processing of Garn Ghzel variety.

Hence, the objective of this work is to produce pulp, pomace powders and syrup from Garn Ghzel date variety, to determine their 
physicochemical and functional properties and to model their freeze drying kinetic.

\section{Materials and methods}

\subsection{Vegetable materials}

Date fruit (Garn Ghzel variety) was harvested at full maturity (Tamr) and stored at $4^{\circ} \mathrm{C}$ in a refrigerator, (SUMSUNG, South Korea). It was purchased from the region of Sidi Okba (Biskra, Algeria). The fruit was washed using water and divided into 2 parts; the first part used to characterize the pulp, the second part to produce date syrup and pomace.

Date syrup was prepared according to Alfarsi (2003) method with a slight modification: A chopper was used to cut dates into pieces of 1 $\mathrm{cm}$, then dates were mixed with an equal amount of distilled water. The mixture was stirred for 20 min at $60^{\circ} \mathrm{C}$ in a water bath, (DK-420, China).
Finally, the juice was extracted through a muslin cloth. Filtration was performed in two steps; coarse $(50 \mu$ filter paper $)$ and fine $(3 \mu$ filter paper).

Concentration was performed on a hot plate, (IKA-COMBIMAG RCT, Germany) $\left(90^{\circ} \mathrm{C}\right)$ (Daas Amiour et al., 2014), until syrup reached $35^{\circ}$ Brix.

Date pulp and pomace were freeze dried in a laboratory freeze dryer model (LD 2-8 CHRIST BETA PLUS, Germany) for 24 hours at a pressure and temperature of $0.12 \mathrm{mbar}$ and $40^{\circ} \mathrm{C}$ respectively. The thickness of date pulp and pomace was measured using digital caliper, LCD screen $0.01 \mathrm{~mm}-150 \mathrm{~mm}$ (Electronic Vernier, UK) (Goula Athanasia and Adamopoulos Konstantinos, 2004). Samples were ground and sieved in a sieve of $1 \mathrm{~mm}$ diameter (Figure 1).

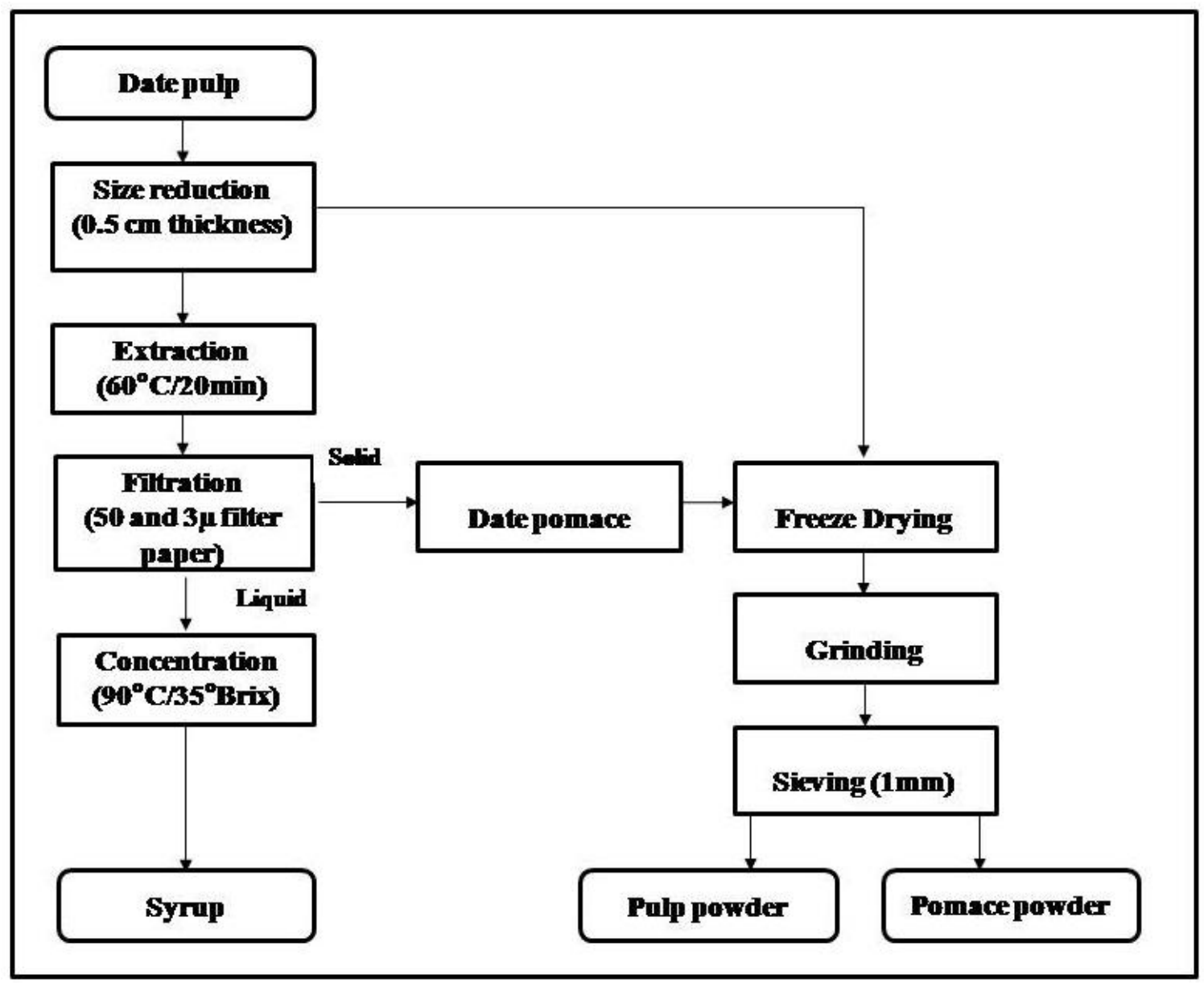

Figure 1. Simplified flowchart of date powders and syrup processing 
2.2. Physicochemical and functional analysis of powders and syrup

\subsubsection{Physicochemical analysis}

For powders, moisture content was determined by drying at $70^{\circ} \mathrm{C}$ to obtain constant weight in a moisture analyzer, (RADWAG MA 110.R.NS, Poland) and moisture loss expressed as a percentage of $(100 \mathrm{~kg}$ water / $\mathrm{kg}$ wet material) (Goula Athanasia and Adamopoulos Konstantinos, 2004). For syrup, moisture content was obtained by drying at $105^{\circ} \mathrm{C}$ in a forced convection laboratory oven, (ESCO isotherm, USA) until constant weight (Gurak et al., 2014).

Water activity of date pulp and pomace powders was measured using water activity meter model (rotronic HYGROSCOP BT-

RS1, Gemini BV), set at $24.70 \pm 1{ }^{\circ} \mathrm{C}$ (Caparino et al., 2012). For date syrup, water activity was measured according to Fennir et al. (2003) with a slight modification, where samples have the same concentration and prepared without dilution.

For date powders and syrup, ash was determined by combustion of the sample in a muffle furnace, (Nabertherm $30-3000^{\circ} \mathrm{C}$, Germany) at $550^{\circ} \mathrm{C}$ for $8 \mathrm{~h}$ (Abbès et al., 2011).

Soluble solids content of date powders and syrup was determined using a digital refractometer, (ATAGO, HSR500, Japan) (Kulkarni et al., 2008).

Titrable acidity was determined by titrating a known quantity of sample with $0.1 \mathrm{~N} \mathrm{NaOH}$ and expressed as citric acid (Kulkarni et al., 2008).

$\mathrm{pH}$ was determined according to standard ISO 10390 (1994); the method consists of preparing a suspension component in five times its volume of distilled water, leave for 5 minutes then rest for at least two hours but no more than 24 hours. $\mathrm{pH}$ is measured using a $\mathrm{pH}$ meter, (HACH, France) (Kulkarni et al., 2008).

Color: Powders and date syrup were poured into Petri dishes, formed a layer of $10 \mathrm{~mm}$ thick and covered with a transparent film. The colorimeter, (KONICA MINOLTA SENSING, INC CR-10, Japan) was calibrated with a standard white ceramic plate before playback (L $=95.97, \mathrm{a}=\quad-0.13, \mathrm{~b}=-0.30) \mathrm{L}, \mathrm{a}, \mathrm{b}$ parameters were measured for all samples. The average values $\mathrm{L}$, $\mathrm{a}$ and $\mathrm{b}$ were obtained from six readings for each sample (Abonyi et al., 2002).

\subsubsection{Functional analysis}

Density of syrup was calculated using the following equation:

Density $=\frac{\text { weight of syrup volume }}{\text { weight of the same volume of distilled water at } 4^{\circ} \mathrm{C}}(1)$

Weighing is conducted using a precision balance model (RADWAG, AS 220.R2, Poland) with reading accuracy of $0.0001 \mathrm{~g}$ and maximum capacity of $220 \mathrm{~g}$ (Mimouni, 2015).

Water holding capacity (WHC) is determined by the method described by AACC (1995); $2 \mathrm{~g}$ of powders put in $200 \mathrm{ml}$ of distilled water, were stirred for 30 seconds with a glass rod. The mixture rested 10 minutes, the stirring operation was repeated five times. Tubes were centrifuged for $20 \mathrm{~min}$ at $4000 \mathrm{rev} / \mathrm{min}$ in a centrifuge, (SIGMA 6-16 KS, Germany). The supernatant was carefully decanted, then the content of the tube was dried at $45^{\circ} \mathrm{C}$ for 10 minutes in an oven, (ESCO isotherm, USA) before being weighed, using a standard scale, (RADWAG, AS 220.R2, Poland). The water holding capacity was expressed as percentage increase in the sample's weight (Adepeju et al., 2014).

The index of wettability is measured from the results obtained during the rehydration of powder without stirring. It is expressed as the time in seconds required for a given amount of powder to enter the water through its free surface at rest (Schuck et al., 2012).

Dispersibility: $10 \mathrm{ml}$ of distilled water at $25^{\circ} \mathrm{C}$ were poured into a beaker of $50 \mathrm{ml} . \quad 1 \mathrm{~g}$ of powder was added in the beaker. The stopwatch started and the sample stirred vigorously with a spoon for 15 seconds by 25 full movements back and forth across the diameter of the container. Reconstituted honey was poured through a sieve (112 microns). $1 \mathrm{ml}$ of sieved honey was transferred into an aluminum pan weighed and dried for 2 hours in 
a vacuum oven $70 \pm 1^{\circ} \mathrm{C}$ model (BINDER, Germany).

Dispersibility of the powder was calculated as follows:

$$
\mathrm{D}(\%)=\frac{(10+\mathrm{m}) \times \mathrm{TS}}{\mathrm{m} \times((100-\mathrm{MC}) / 100))}
$$

$\mathrm{m}$ : amount of powder ( $\mathrm{g}$ ) being used, MC: Moisture content in the powder (db) and TS\%: dry matter in of reconstituted honey after it has been passed through the sieve (Koç and Kaymak-Ertekin, 2014).

True density: determined as the ratio of the mass of dry solids $(\mathrm{m})$ to total volume (Vs) of the sample excluding the air ports (CalínSánchez et al., 2014):

$$
\rho_{\mathrm{t}}=\frac{\mathrm{m}}{\mathrm{Vs}}
$$

Samples were weighted with an analytical balance, (RADWAG, AS 220.R2, Poland), while Vs was measured with a pycnometer model (ISO LAB In $20^{\circ} \mathrm{C}, 10 \mathrm{ml}$ BORO $3.3 \mathrm{~A}$, Germany).

Bulk density: Determined as the ratio of solid mass to the bulk volume (Vb). Samples were weighted with the analytical balance, (RADWAG, AS 220.R2, Poland) with reading accuracy of $0.0001 \mathrm{~g}$ and the bulk volume was measured with an $80 \mathrm{~mL}$ graduated container (Calín-Sánchez et al., 2014):

$$
\rho b=\frac{m}{V b}
$$

\subsubsection{Mathematical modeling of freeze drying kinetics}

Moisture ratio (MR) of date (pulp and pomace) during freeze drying was calculated using the following equation:

$$
\mathrm{MR}=\frac{\mathrm{Mt}-\mathrm{Me}}{\mathrm{M} 0-\mathrm{Me}}
$$

Where: Mt, M0 and Me are moisture content at any time, the initial moisture and the equilibrium moisture ( $\mathrm{g}$ water / $\mathrm{g}$ dry matter), respectively (Erbay and Icier, 2009).
The effective moisture diffusivity can be defined from Fick's second law of diffusion, which describes the movement of moisture within the solid.

$\frac{\delta \mathrm{M}}{\delta \mathrm{t}}=\mathrm{D} \frac{\delta^{2} \mathrm{M}}{\delta \mathrm{Z}^{2}}$

Analytical solution of this law in the case of drying an infinite slab of thin layer, assuming moisture migration being by diffusion, onedimensional moisture movement, uniform initial moisture distribution, negligible shrinkage, constant moisture diffusivity, and negligible external resistance to heat and mass transfer can be developed in the form of the following equation (Crank, 1975).

$$
\frac{\mathrm{M}-\mathrm{M}_{\mathrm{e}}}{\mathrm{M} 0-\mathrm{M}_{\mathrm{e}}}=\frac{8}{\pi^{2}} \sum_{\mathrm{n}=1}^{\infty} \frac{1}{(2 \mathrm{n}-1)} \exp \left[-(2 \mathrm{n}-1)^{2} \frac{\pi^{2}}{4} \frac{\mathrm{Dt}}{\mathrm{L}^{2}}\right]
$$

Where $\mathrm{L}$ is the thickness $(\mathrm{m}) ; \mathrm{t}$ is the time (min); and $\mathrm{D}$ is the effective diffusivity $\left(\mathrm{m}^{2} / \mathrm{s}\right)$. Simplifying the previous equation by taking the first term of the series solution and assuming $\mathrm{M}_{\mathrm{e}}$ equal to 0 :

$$
\mathrm{MR}=\frac{\mathrm{M}}{\mathrm{M} 0}=\frac{8}{\pi^{2}} \cdot \exp \left[-\frac{\pi^{2}}{4} \frac{\mathrm{Dt}}{\mathrm{L}^{2}}\right]
$$

Where L the thickness of the sample and D the effective diffusion coefficient.

Taking logarithm on both sides of previous equation gives the following equation ( $\mathrm{Nag}$ and Dash, 2016):

$$
\operatorname{Ln} M R=\left(\operatorname{Ln} \frac{8}{\pi^{2}}\right)-\frac{\pi^{2} D t}{4 L^{2}}
$$

The diffusion coefficient (D) is calculated using the method of slopes.

$$
\text { Slope }=-\left(\frac{\pi^{2} \mathrm{D}}{4 \mathrm{~L}^{2}}\right)
$$

Drying kinetics of date pulp and pomace were fitted to five models (Newton, Page, Henderson and Papis, Logarithmic, Wang and Singh). The quality of the adjustment was determined using the coefficient of 
determination $\left(\mathrm{R}^{2}\right)$, the reduced $\chi$-square $\left(\chi^{2}\right)$ (Ergun et al., 2014) and root mean square error (RMSE) as follows:

$$
\begin{aligned}
& \chi^{2}=\frac{\sum_{\mathrm{i}=1}^{\mathrm{N}}(\operatorname{MRexp}(\mathrm{i})-\operatorname{MRpre}(\mathrm{i}))^{2}}{\mathrm{~N}-\mathrm{n}} \\
& \mathrm{RMSE}=\sqrt{\frac{\sum_{\mathrm{i}=1}^{\mathrm{N}}(\operatorname{MRpre}(\mathrm{i})-\mathrm{MRexp}(\mathrm{i}))^{2}}{\mathrm{~N}}}
\end{aligned}
$$

Where $\mathrm{MR}_{\text {expi }}$ is the $i$ th experimental moisture ratio, $\mathrm{MR}_{\text {prei }}$ is the $i$ th predicted moisture ratio, $\mathrm{N}$ is the number of observations, $\mathrm{n}$ is the number of constants in drying model (Pardeshi et al., 2009).

\subsubsection{Statistical analysis}

Analyses were performed with three replications, while color with six and results expressed as the mean \pm standard deviation (SD). Results were submitted to the analysis of variance (ANOVA) and means were compared by Tukey's test using Origin Pro 201632 Bit software. Differences were considered to be significant at $\mathrm{P}<0.05$.

\section{Results and discussions \\ 3.1. Production of powders}

$100 \mathrm{~g}$ of pulp and pomace were freeze dried at a temperature of $-40^{\circ} \mathrm{C}$ and a pressure of 0.12 mbar (Fig 1). After 24h, samples weight became $96.70 \mathrm{~g}$ and $63.50 \mathrm{~g}$ respectively.

Pulp and pomace samples have an initial water content of 0.11 and $0.45\left(\mathrm{~kg} \mathrm{H} \mathrm{H}_{2} \mathrm{O} / \mathrm{kg}\right.$ product) respectively. The relative water content of pomace decreases and reaches a level of 0.55 after $12 \mathrm{~h}$. However, pulp reaches a value of 0.94 after $12 \mathrm{~h}$, these results agree with Sahari et al. (2008) who studied the effect of initial moisture and date thickness on the drying process.

\subsection{Physicochemical properties of powders}

Physicochemical properties of date powders are shown in Table 1.

Table 1. Physicochemical properties of pulp and pomace powders

\begin{tabular}{|c|c|c|}
\hline Parameters & Pulp powder & Pomace powder \\
\hline Moisture (\%) & $2.50 \pm 0.05$ & $7.64 \pm 0.22$ \\
\hline Water activity & $0.17 \pm 0.22$ & $0.32 \pm 0.02$ \\
\hline Ash (g/100g) & $0.84 \pm 0.04$ & $1.00 \pm 0.01$ \\
\hline Soluble solids content ( ${ }^{\circ}$ Brix) & $60 \pm 0.00$ & $59.90 \pm 0.17$ \\
\hline Titrable acidity (\% citric acid) & $3.03 \pm 0.20$ & $2.57 \pm 0.20$ \\
\hline pH & $6.28 \pm 0.05$ & $6.36 \pm 0.02$ \\
\hline Color $\left(\mathbf{L}^{*}\right)$ & $78.57 \pm 0.23$ & $68.9 \pm 0.36$ \\
\hline Color $\left(\mathbf{a}^{*}\right)$ & $4.41 \pm 0.12$ & $7.10 \pm 0.09$ \\
\hline Color $\left(\mathbf{b}^{*}\right)$ & $22.43 \pm 0.29$ & $25.00 \pm 0.17$ \\
\hline
\end{tabular}

Results are expressed as mean values of three determinations $\pm \mathrm{SD}$; analysis of variance (ANOVA) $\mathrm{p}<0.05$ with Tukey's tests.

Color results are expressed as mean values of six determinations $\pm \mathrm{SD}$

Moisture content of pulp and pomace powders were $2.50 \pm 0.05$ and $7.64 \pm 0.22 \%$ respectively. These results are similar to moisture content values of freeze dried papaya and pineapple, 2 and $7 \%(\mathrm{wb})$ respectively (Marques et al., 2011).
However, they were higher than freeze dried marionberries and strawberries cultivars (0.10-0.20\%) and corn cultivars (0.70-1.10\%) (Asami et al., 2003).

Titratable acidity of pulp and pomace powders were $3.03 \pm 0.20,2.57 \pm 0.20$ (\% citric acid) respectively. They were higher than 
freeze-dried papaya pulp powders with a value of $1.38 \pm 0.07 \%$ citric acid (Canuto et al., 2014).

$\mathrm{pH}$ of date powders was almost similar with values of $6.28 \pm 0.05$ and $6.36 \pm 0.02$ of pulp and pomace powders respectively. These results were closer to those reported by Mahendran (2010) for freeze dried guava.

Microbiological, chemical and enzymatic stability of food products is related to water activity content $\left(\mathrm{a}_{\mathrm{w}}\right)$, values of water activity ranging between 0.20 and 0.40 ensure stability of the product (Nur Dirim and Çalişkan, 2012), the $\mathrm{a}_{\mathrm{w}}$ of pulp and pomace powders were $0.17 \pm 0.22$ and $0.32 \pm 0.02$ respectively. These values were similar to water activity value of freeze dried pumpking puree powder found as 0.20 (Nur Dirim and Çalişkan, 2012). Ashes and total soluble solids have values of $0.84 \pm 0.04$, $1.00 \pm 0.01 \quad(\mathrm{~g} / 100 \mathrm{~g}) \quad$ and $60 \pm 0.00$, $59.90 \pm 0.17^{\circ}$ Brix for pulp and pomace powders respectively. These values were similar to those reported in literature for samples of Mech Degla date powder $1.44 \pm 0.20(\mathrm{~g} / 100 \mathrm{~g})$ and $60^{\circ}$ Brix.

Food color is a major determinant of product quality and affects consumer preferences. Color may be used as an indicator to predict chemical and quality change due to thermal processing (Valdenegro et al., 2013). Color parameters (L*, $\left.a^{*}, b\right)$ of pulp and pomace powders were shown in Table 1. Pulp and pomace powders were slightly orange $\left(\mathrm{a}^{* 4.41 \pm 0.12) \quad \text { and }}\right.$ $\left(a^{* 7.10 \pm 0.09)}\right.$, slightly yellow $\left(b^{* 22.43 \pm 0.29)}\right.$ and $(b * 25.00 \pm 0.17)$ respectively, the difference in color parameters is due to product composition. Similar L*, $\mathrm{a}^{*}$, and $\mathrm{b}^{*}$ values were reported by Sablani et al. (2008) for date powder (Mech degla variety).

\subsection{Functional properties of powders}

Table 2 shows functional properties of pulp and pomace powders. Water holding capacity (WHC), wettability index and dispersibility show the ability of powders to rehydrate.

Table 2. Functional properties of pulp and pomace powders

\begin{tabular}{|c|c|c|}
\hline Parameters & Pulp powder & Pomace powder \\
\hline Water holding capacity (g water/g dry matter) & $0.63 \pm 0.23$ & $0.70 \pm 0.02$ \\
\hline Wettability index (s) & $930 \pm 0.50$ & $1425 \pm 0.33$ \\
\hline Dispersibility (\%) & $91.76 \pm 0.21$ & $68.51 \pm 0.40$ \\
\hline True density $\mathbf{( K g / \mathbf { m } ^ { 3 } )}$ & $884.96 \pm 0.00$ & $454.55 \pm 0.00$ \\
\hline Bulk density $\mathbf{( K g / \mathbf { m } ^ { 3 } )}$ & $909.00 \pm 0.00$ & $505.05 \pm 0.00$ \\
\hline
\end{tabular}

Results are expressed as mean values of three determinations $\pm \mathrm{SD}$; analysis of variance (ANOVA) $\mathrm{p}<0.05$ with Tukey's tests.

According to Gurak et al. (2014), WHC is defined as the amount of water retained by the sample without being subjected to any stress. Pulp powder has a WHC value less than pomace with values of $0.63 \pm 0.23$ and $0.70 \pm 0.02$ (g of water / g dry matter) respectively. These results were lower than those obtained by Nguyen (2014) with values of 0.90 to 1.00 (g eau/ $\mathrm{g}$ powder) for soy powders produced by atomization and between 3.97 and $6.20 \mathrm{~g} / \mathrm{g}$ dry fiber for date fiber concentrates varieties (Borchani et al., 2010). The difference is due to composition and varieties. The wettability or the ability of powder to absorb water is one of the most important physical properties related to reconstituting powders (Sarabandi et al., 2014). The obtained results were $930 \pm 0.50$ (s) for pulp which is lower than $1425 \pm 0.33$ (s) for pomace. According to Manickavasagan et al. (2015), date powder obtained by spray drying has a wettability time ranged between 145.70 and 162.70 (s), dispersibility values of pulp and pomace powders were $91.76 \pm 0.21$ and $68.51 \pm 0.40 \%$ respectively. These values are higher than results obtained by Koç and Kaymak-Ertekin (2014), ranging between 51.30 and $100 \%$ for spray dried honey powder. 
Bulk density of powders is determined by particle density, which is determined by solid density and particle internal porosity, and also by spatial arrangement of particles in the container (Micha, 2005). True and bulk density (Table 2) of powder samples were $884.96 \pm 0.00$ $909.00 \pm 0.00 \mathrm{Kg} / \mathrm{m}^{3}$ and $454.55 \pm 0.00$ $505.05 \pm 0.00 \mathrm{Kg} / \mathrm{m}^{3}$ respectively. Pulp powder density was higher than pomace powder and bulk density was also higher than the true density. The difference is justified since powder heap reduces the space between particles, so volume will decrease. The obtained results were similar to Calín-Sánchez et al. (2014) results regarding freeze dried chokeberry fruits.

\subsection{Physicochemical properties of syrup}

Date syrup is an important date by-product and a natural sweetener considered as a suitable replacement of sugar in food products formulation, in order to reduce the harmful effect of sugar, and improving the nutrient properties (Raiesi Ardali et al., 2014). Physicochemical properties of syrup were shown in Table 3.

Table 3. Physicochemical properties of date syrup

\begin{tabular}{|c|c|}
\hline Parameters & Date syrup \\
\hline Moisture (\%) & $61.81 \pm 0.08$ \\
\hline Water activity & $0.92 \pm 0.01$ \\
\hline Ash (g/100g) & $1.02 \pm 0.99$ \\
\hline $\begin{array}{c}\text { Soluble solids } \\
\text { content }\left({ }^{\circ} \text { Brix) }\right.\end{array}$ & $35 \pm 0.00$ \\
\hline $\begin{array}{c}\text { Titrable acidity } \\
\text { \% citric acid) }\end{array}$ & $0.58 \pm 0.20$ \\
\hline pH & $6.22 \pm 0.06$ \\
\hline Color $\left(\mathbf{L}^{*}\right)$ & $33.06 \pm 0.23$ \\
\hline Color $\left(\mathbf{a}^{*}\right)$ & $0.60 \pm 0.00$ \\
\hline Color $\left(\mathbf{b}^{*}\right)$ & $6.93 \pm 0.14$ \\
\hline Density $(\mathbf{g} / \mathbf{m l})$ & $1.20 \pm 0.02$ \\
\hline
\end{tabular}

Results are expressed as mean values of three determinations $\pm \mathrm{SD}$; analysis of variance (ANOVA) $\mathrm{p}<0.05$ with Tukey's tests. Color results are expressed as mean values of six determinations \pm SD. Moisture content and water activity of date syrup are $61.81 \pm 0.08 \%$ and $0.92 \pm 0.01$ respectively, these results are similar to Ganbi (2012) with values of $74.06 \pm 6.10 \%$ for water bath date fruits juice (Dibs) and Fennir et al. (2003) for Saidi date syrups with values of 0.881 . The difference could be due to date varieties. Syrup ash content is $1.02 \pm 0.99(\mathrm{~g} / 100 \mathrm{~g})$, this result is lower than Raiesi Ardali and Akbarian (2014) who found a value of $1.69(\mathrm{~g} / 100 \mathrm{~g})$. Total soluble solids, titrable acidity and $\mathrm{pH}$ have values of $35 \pm 0.00^{\circ}$ Brix, $0.58 \pm 0.20$ (\% citric acid) and $6.22 \pm 0.06$ respectively, which are closer to values reported by Farahnaky et al. (2016); ElSharnouby et al. (2014) and Ganbi (2012) respectively. Density has a value of $1.20 \pm 0.02$ $(\mathrm{g} / \mathrm{ml})$ which is similar to Jamshidi Mokhber et al. (2008) with a value of $1.35(\mathrm{~g} / \mathrm{ml})$. Color parameters $\left(\mathrm{L}^{*}, \mathrm{a}^{*}, \mathrm{~b}\right)$ of syrup were shown in Table 3. Syrup was slightly orange $\left(\mathrm{a}^{*} 0.60 \pm 0.00\right)$ and slightly yellow $\left(\mathrm{b}^{*} 6.93\right.$ $\pm 0.14)$. Similar $\mathrm{L}^{*}, \mathrm{a}^{*}$, and $\mathrm{b}^{*}$ values were reported by Raiesi Ardali and Akbarian (2014); Fennir et al. (2003) for date syrup. 
Table 4. Model constants and statistical parameters for date pulp and pomace

\begin{tabular}{|c|c|c|c|c|c|}
\hline \multicolumn{6}{|c|}{ Date pulp } \\
\hline Models & Equations & $\begin{array}{l}\text { Constants and } \\
\text { coefficients }\end{array}$ & $\mathbf{R}^{2}$ & $\chi^{2}$ & RMSE \\
\hline Newton & $\mathrm{MR}=\exp (-\mathrm{kt})$ & $\mathrm{k}=0.00450$ & 0.9403 & 0.000030 & 0.00152 \\
\hline Page & $\mathrm{MR}=\exp \left(-\mathrm{kt}^{\mathrm{n}}\right)$ & $\begin{array}{l}\mathrm{k}=0.00231 \\
\mathrm{n}=1.29878\end{array}$ & 0.9635 & 0.000021 & 0.00390 \\
\hline $\begin{array}{c}\text { Henderson and } \\
\text { Papis }\end{array}$ & $\mathrm{MR}=\mathrm{aexp}(-\mathrm{kt})$ & $\begin{array}{c}\mathrm{a}=1.00538 \\
\mathrm{k}=0.00512\end{array}$ & 0.9613 & 0.000022 & 0.00401 \\
\hline Logarithmic & $\mathrm{MR}=\mathrm{aexp}(-\mathrm{kt})+\mathrm{c}$ & $\begin{array}{c}\mathrm{a}=24.13641 \\
\mathrm{k}=0.00021 \\
\mathrm{c}=-23.13126\end{array}$ & 0.9619 & 0.000028 & 0.00398 \\
\hline Wang and Singh & $\mathrm{MR}=1+\mathrm{at}+\mathrm{bt}^{2}$ & $\begin{array}{l}a=-0.00443 \\
b=-0.00005\end{array}$ & 0.9630 & 0.000027 & 0.00392 \\
\hline \multicolumn{6}{|c|}{ Date pomace } \\
\hline Models & Equations & $\begin{array}{c}\text { Constants and } \\
\text { coefficients }\end{array}$ & $\mathbf{R}^{2}$ & $\chi^{2}$ & RMSE \\
\hline Newton & $\mathrm{MR}=\exp (-\mathrm{kt})$ & $\mathrm{k}=0.07042$ & 0.6691 & 0.009080 & 0.08811 \\
\hline Page & $\mathrm{MR}=\exp \left(-\mathrm{kt}^{\mathrm{n}}\right)$ & $\begin{array}{l}\mathrm{k}=0.25645 \\
\mathrm{n}=0.37086\end{array}$ & 0.9774 & 0.007420 & 0.02307 \\
\hline $\begin{array}{c}\text { Henderson and } \\
\text { Papis }\end{array}$ & $\mathrm{MR}=\mathrm{aexp}(-\mathrm{kt})$ & $\begin{array}{l}\mathrm{a}=0.89177 \\
\mathrm{k}=0.05420\end{array}$ & 0.7824 & 0.007160 & 0.07152 \\
\hline Logarithmic & $\mathrm{MR}=\mathrm{aexp}(-\mathrm{kt})+\mathrm{c}$ & $\begin{array}{l}a=0.45683 \\
k=0.41041 \\
c=0.54464\end{array}$ & 0.9987 & 0.000052 & 0.00546 \\
\hline Wang and Singh & $\mathrm{MR}=1+\mathrm{at}+\mathrm{bt}^{2}$ & $\begin{array}{l}a=-0.10019 \\
b=0.00566\end{array}$ & 0.9688 & 0.001290 & 0.02710 \\
\hline
\end{tabular}

\subsection{Mathematical modeling of freeze drying kinetics}

The freeze drying behavior was determined from the loss of samples weight. Total drying time was determined as 12 hours for the pulp and pomace samples. Similar results were obtained by Marques et al. (2011) for freeze dried pineapple, guava and mango pulp.

The experimental data were fitted using Origin Pro 201632 Bit software to five models (Newton, Page, Henderson and Papis, Logarithmic and Wang and Singh) (Table 4). The correlation coefficient $\left(\mathrm{R}^{2}\right)$ was used to define the best model of the drying process for the pulp and pomace date, with $\chi^{2}$ having the lowest value (Togrul and Pehivan, 2002).

Figure 2 represents the experimental data of water content with the best mathematical model for pulp and pomace date. 

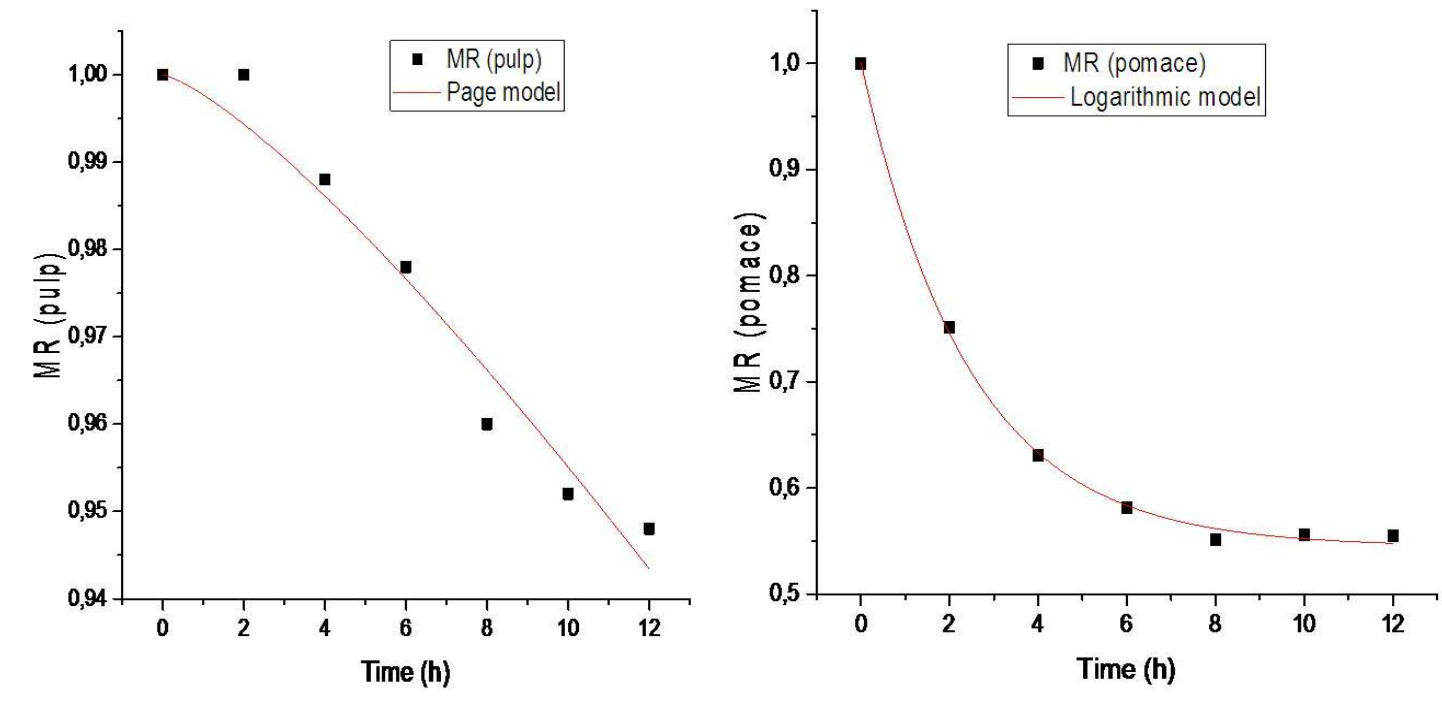

Figure 2. Plot of moisture ratio versus drying time for freeze dried pulp and pomace date (Page and Logarithmic models)

Diffusivity values were ranged between 9.74 $\times 10^{-11}$ and $5.15 \times 10^{-11} \mathrm{~m}^{2} / \mathrm{s}$ for pulp and pomace respectively. These values are within the range reported by Ergun et al. (2014) for the foods ranging from $10^{-12}$ to $10^{-6}\left(\mathrm{~m}^{2} / \mathrm{s}\right)$.

\section{Conclusions}

This study investigated the production and characterization of pulp and pomace date powders as well as date syrup from Garn Ghzel variety. Powders were obtained using freeze drying process. The Garn Ghzel variety date shows interesting physicochemical and functional characteristics. The freeze drying process of pulp and pomace date was modeled and best fitted to Page and Logarithmic models respectively.

\section{References}

Abbès, F., Bouaziz, M.A., Blecker, Ch., Masmoudi, M., Attia, H., Besbes, S. (2011). Date syrup: Effect of hydrolytic enzymes (pectinase/cellulase) on physicochemical characteristics, sensory and functional properties. LWT-Food Science and Technology, 44, 1827-1834.

Abonyi, B.I., Feng, B.I., Edwards, C.G., Tang, J. (2002). Quality retention in strawberry and carrot purees dried with Refractance Window system. Journal of Food Science, 67(3), 1051-1056.

Adepeju, A.B., Gbadamosi, S.O., Omobuwajo, T.O., Abiodun, O.A. (2014). Functional and physico-chemical properties of complementary diets produced from breadfruit (Artocarpus altilis). African Journal of Food Science, 5(4), 105-113.

Al-Farsi, M.A. (2003). Clarification of date juice. International Journal of Food Science and Technology, 38, 241-245.

Al-Shahib, W., Marshall, R.J. (2003). The fruit of the date palm: it's possible use as the best food for the future?. International Journal of Food Sciences and Nutrition, 54(4), 247259.

Asami, DK., Hong, YJ., Barrett, D.M., Mitchell, AE. (2003). Comparison of the total phenolic and ascorbic acid content of freezedried and air-dried marionberry, strawberry, and corn grown using conventional, organic, and sustainable agricultural practices. Journal of Agricultural and Food Chemistry, 51(5), 1237-1241.

Borchani, Ch., Besbes, S., Blecker, Ch., Masmoudi, M., Baati, R., Attia, H. (2010). Chemical properties of 11 date cultivars and 
their corresponding fiber extracts. African Journal of Biotechnology, 9(26), 40964105.

Calín-Sánchez, A., Kharaghani, A., Lech, K., Figiel, A., Carbonell-Barrachina, A.A., Tsotsas, E. (2014). Physical and sensory properties of chokeberry fruits dried with different methods. 19th International Drying Symposium, August 24-27, Lyon, France, 16.

Canuto, H.M.P., Afonso, M.R.A., Costa José, M.C. (2014). Hygroscopic behavior of freeze-dried papaya pulp powder with maltodextrin. Acta Scientiarum. Technology, 36(1), 179-185.

Caparino, O.A., Tang, J., Nindo, C.I., Sablani, S.S., Powers, J.R., Fellman, J.K. (2012). Effect of drying methods on the physical properties and microstructures of mango (Philippine 'Carabao' var.) powder. Journal of Food Engineering, 111(1), 135-148.

Crank, J. (1975). The mathematics of diffusion. (2nd ed.). London W.I.: Oxford.

Daas Amiour, S., Alloui-Lombarkia, O., Bouhdjila, F., Ayachi, A., Hambaba, L. (2014). Study of the involvement of phenolic compounds of extracts of three date varieties in its antibacterial activity. Phytotherapy, 12, 135-142.

El-Sharnouby G.A., Aleid S.M., Al-Otaibi M.M. (2014). Liquid Sugar Extraction from Date Palm (Phoenix dactyliferaL.) Fruits. Journal of Food Processing and Technology, 5(12), 41-47.

Erbay, Z., Icier, F.A. (2009). Review of thin layer drying of foods: theory, modeling, and experimental results. Critical Reviews in Food Science and Nutrition, 50, 441-464.

Ergun, K., Caliskan, G., Dirim, S.N. (2014). Determination of the freeze drying kinetics of kiwi (actinidia deliciosa) puree with and without the addition of maltodextrin. 19th International Drying Symposium, August 24-27, Lyon, France, 1-4.

Farahnaky, A., Mardani, M., Mesbahi, Gh., Majzoobi, M., Golmakani, M. T. (2016). Some Physicochemical Properties of Date Syrup, Concentrate, and Liquid Sugar in
Comparison with Sucrose Solutions. Journal of Agricultural Science and Technology, 18, 657-668.

Fennir, M.A., Landry, J.A., Ramaswamy, H.S., Raghavan, V.G.S. (2003). An investigation of sugar extraction methods and the use of microwave power for date syrup processing Efficiency and color related considerations. Journal of Microwave Power and Electromagnetic Energy, 38(3), 189-196.

Ganbi, H.H.A. (2012). Production of Nutritious High Quality Date (Phoenix dactylifera) Fruits Syrup (Dibs) by using some Novel Technological Approaches. Journal of Applied Sciences Research, 8(3), 15241538.

Goula Athanasia, M., Adamopoulos Konstantinos, G. (2004). Spray Drying of Tomato Pulp: Effect of Feed Concentration. Journal of Food Engineering, 22(10), 23092330.

Gurak, P.D., De Bona, G.S., Tessaro, I.C., Marczak, L.D.F. (2014). Jaboticaba Pomace Powder Obtained as a Co-product of Juice Extraction: A Comparative Study of Powder Obtained from Peel and Whole Fruit. Food Research International, 62, 786-792.

Jamshidi Mokhber, M., Alemzadeh, I., Vossoughi, M. (2008). Optimization of hfds production from date syrup. International Journal of Engineering, Transactions B: Applications, 21(2), 127-134.

Koç, M., Kaymak-Ertekin, F. (2014). Effect of spray drying conditions on hydroxymethylfurfural content and physical properties of honey powder. 19th International Drying Symposium, August 24-27, Lyon, France, 1-7.

Kulkarni, S.G., Vijayanand, P., Aksha, M., Reena, P., Ramana, K.V.R. (2008). Effect of dehydration on the quality and storage stability of immature dates (Pheonix dactylifera). LWT- Food Science and Technology, 41(2), 278-283.

Mahendran, T. (2010). Physico-chemical properties and sensory characteristics of dehydrated guava concentrate: effect of drying method and maltodextrin 
concentration. Tropical Agricultural Research and Extension, 13(2), 49-54.

Manickavasagan, A., Thangavel, K., Dev, S.R.S., Aniesrani Delfiya, D.S., Nambi, E., Orsat, V. Raghavan, G.S.V. (2015). Physicochemical Characteristics of Date Powder Produced in a Pilot Scale Spray Dryer. Drying Technology, 33, 1114-1123.

Marques, LG., Prado, MM., Freire, JT. (2011). Vitamin C content of freeze-dried tropical fruits. International Congress on Engineering and Food, May 22-26, Athens, Greece, Vol III, 1-6.

Micha, P. (2005). Physical properties of food powders. Food Engineering, 1, 1-9.

Mimouni, Y. (2015). Development of dietary hypoglycemic products based on soft dates "Ghars" variety, the most widespread in the Ouargla basin. (Doctoral dissertation), University of Kasdsi Merbah, Ouargla, Algeria, 169p.

Mrabet, A., Ferchichi, A., Chaira, N., Ben salah, M. (2008). Physico-chemical characteristics and total quality of date palm varieties grown in the southern of Tunisia. Pakistan Journal of Biological Sciences, 11(7), 10031008.

Nag, S., Dash, K.K. (2016). Mathematical modeling of thin layer drying kinetics and moisture diffusivity study of elephant apple. International Food Research Journal, 23(6), 2594-2600.

Nireesha, GR., Divya, L., Sowmya, C., Venkateshan, N., Niranjan Babu, M., Lavakumar, V. (2013). Lyophilization/Freeze Drying-An Review. International Journal of Novel Trends in Pharmaceutical Sciences, 3(4), 87-98.

Nguyen, D.Q. (2014). Experimental comparative study of atomization and autovaporization operations: Arabic Gum and Soya application. (Doctoral dissertation), University of La Rochelle, France. 212p.

Nur Dirim, S., Çalışkan, G. (2012). Determination of the effect of freeze drying process on the production of pumpkin (cucurbita moschata) puree powder and the powder properties. GIDA/The Journal of Food, 37(4), 203-210.

Omolola Adewale, O., Jideani Afam, I.O., Kapila Patrick, F. (2015). Quality properties of fruits as affected by drying operation. Critical Reviews in Food Science and Nutrition, (accept manuscript).

Raiesi Ardali, F., Rahimi, E., Tahery, S., Shariati, M. A. (2014). Production of a New Drink by Using Date Syrup and Milk. Journal of Food Biosciences and Technology, 4(2), 67-72.

Raiesi, A.F., Akbarian, M. (2014). The Influence of Date Syrup on Color, Texture and Sensory Properties of Gaz. Bulletin of Environment, Pharmacology and Life Sciences, 3(2), 159-163.

Sablani S., S., Shrestha A., K., Bhandari, B., R. (2008). A new method of producing date powder granules: Physicochemical characteristics of powder. Journal of Food Engineering, 87(3), 416-421.

Sahari, M. A., Hamidi-Esfehani, Z., Samadlui, H. (2008). Optimization of Vacuum Drying Characteristics of Date Powder. Drying Technology, 26(6), 793-797.

Sarabandi, K., Peighambardoust, S. H., Shirmohammadi, M. (2014). Physical properties of spray dried grape syrup as affected by drying temperature and drying aids. International Journal of Agriculture and Crop Sciences, 7(12), 928-934.

Schuck, P., Dolivet, A., Jeantet, R. (2012). Milk and food powders analysis techniques. (1rst ed.). Paris: Tec and Doc-Lavoisier.

Togrul, Y.T., Pehivan, D. (2003). Modelling of drying kinetics of single apricot. Journal of Food Engineering, 58, 23-32.

Valdenegro, M., Almonacid, S., Henríquez, C., Lutz, M., Fuentes, L., Simpson, R. (2013). The Effects of Drying Processes on Organoleptic Characteristics and the Health Quality of Food Ingredients Obtained from Goldenberry Fruits (Physalis peruviana). Scientific Reports, 2(2), 1-7.

Yahaya, S.A., Omokhudu, C.A., Abdulahi, M.A., Sanusi, M.K. (2015). Phytochemical screening and mineral evaluation of fresh 
date fruits (Phoenix dactylifera L.) in wet season of Nigeria. Journal of Agricultural and Crop Research, 3(3), 47-52.

\section{Acknowledgment}

The authors thank all the staff of Food Sciences Laboratory (LSA), Department of Food Technology, Hadj Lakhdar University Batna 1. 